\title{
ANALISIS POTENSI KEHILANGAN PENERIMAAN PAJAK DI INDONESIA (TAHUN 2010-2017)
}

\section{Btari Mutia Anggraeni}

Universitas Bakrie Jakarta, Indonesia

Email: btarimutia@gmail.com

\section{Abstract}

This research is aimed to determine the potential tax loss in Indonesia due to the existence of underground economy activities and the realization of tax revenue in Indonesia. The result of the calculation of potential tax loss based on those two methods will be analysed using the tax regulation published by Government in 2010-2017. The underground economy method is conducted using quantitative approach, namely economic variables, namely currency demand, interest rates, Gross Domestic Product, banking financial innovation, inflation, tax burden and corruption. The potential tax loss in Indonesia during 2010 - 2017 showing a fluctuating trend in the amount of IDR33.82 trillion to IDR92.50 trillion in 2010 and IDR163.22 trillion to IDR180.91 trillion in 2017. The realization of tax revenue method is conducted using income variance which is calculating the difference between the state revenue target from the tax sector and the realization of tax revenue during 2010 - 2017. The potential tax loss in Indonesia from 2010 to 2017 showing a potential of IDR 33.61 trillion in 2010 and IDR 132.54 trillion in 2017. The results of this study indicate that there are differences in the potential tax loss using the two methods which is caused by each tax regulation issued by the government in terms of underground economic's subject and the realization of taxes obtained in current year.

Keywords: underground economy; income variance; potential tax loss; tax regulation

\section{Abstrak}

Penelitian ini bertujuan untuk mengetahui potensi kehilangan penerimaan pajak di Indonesia menggunakan metode underground economy dan realisasi penerimaan pajak di Indonesia. Hasil perhitungan potensi kehilangan penerimaan pajak berdasarkan kedua metode tersebut selanjutnya akan dianalisa menggunakan penerbitan regulasi perpajakan oleh Pemerintah pada tahun 2010-2017. Metode underground economy menggunakan pendekatan kuantitatif yakni variabel ekonomi meliputi permintaan uang kartal, suku bunga, Produk Domestik Bruto, inovasi keuangan perbankan, inflasi, beban pajak dan korupsi. Potensi kehilangan peneriman pajak di Indonesia selama tahun 2010-2017 menggunakan metode ini menunjukkan kecenderungan fluktuatif yakni sebesar Rp33,82 triliun hingga Rp 92,50 triliun pada tahun 2010 dan sebesar Rp163,22 triliun hingga Rp180,91 triliun pada tahun 2017. Metode realisasi penerimaan pajak menggunakan varians pendapatan yakni dihitung dari selisih antara target penerimaan negara dari sektor pajak dengan realisasi penerimaan pajak selama periode 2010-2017. Potensi

How to cite:

E-ISSN:

Published by:
Anggraeni, Btari Mutia (2021) Analisis Potensi Kehilangan Penerimaan Pajak Di Indonesia (Tahun 2010-2017), 6(4). http:// 10.36418/syntax-literate.v6i4.2471

2548-1398

Ridwan Institute 
kehilangan penerimaan pajak di Indonesia tahun 2010-2017 menggunakan metode ini menunjukkan potensi sebesar Rp33,61 triliun pada tahun 2010 dan Rp132,54 triliun pada tahun 2017. Hasil penelitian ini menunjukkan bahwa terdapat perbedaan potensi kehilangan penerimaan pajak menggunakan kedua metode tersebut yang disebabkan oleh setiap regulasi perpajakan yang diterbitkan pemerintah ditinjau dari respon para pelaku underground economy maupun realisasi pajak yang tercapai pada tahun berjalan.

Kata kunci: underground economy; varians pendapatan; kehilangan penerimaan pajak; regulasi perpajakan

\section{Pendahuluan}

Perekonomian Indonesia saat ini mulai menunjukkan keadaan yang semakin membaik. Hal ini terlihat dari meningkatnya pendapatan nasional yang merupakan gambaran perekonomian dari suatu negara. Dengan meningkatnya pendapatan nasional, dapat dikatakan bahwa perekonomian suatu negara juga ikut membaik. Sumber dana terbesar bagi pendapatan nasional di Indonesia berasal dari penerimaan pajak.

Unsur penerimaan pajak terbesar di Indonesia didapat dari penerimaan pajak. Penerimaan pajak digunakan untuk membangun infrastuktur ekonomi masyarakat guna menuju kehidupan sejahtera bagi masyarakat Indonesia (Arfin, 2018).

Realisasi penerimaan pajak di Indonesia tahun 2016 mencapai Rp.1.105,81 triliun atau 81.60\% dari target tahun APBN-P 2016 sebesar Rp.1.355,20 triliun (Direktorat Jenderal Perpajakan, 2016), sedangkan realisasi penerimaan sektor perpajakan tahun 2017 mencapai Rp.1.339,8 triliun atau 91\% dari APBN-P (Detikfinance, 2018). Terdapat beberapa hambatan dalam mencapai target penerimaan pajak diantaranya masalah perekonomian nasional dan internasional hingga korupsi yang terjadi di sektor pajak.

Selain itu, Presiden Jokowi menuturkan bahwa pemerintah mengidentifikasi tidak tercapainya target pajak selama ini diakibatkan adanya underground economy yang sengaja dilakukan untuk menghindari kewajiban administratif dan perpajakan. Beliau mengutip penelitian yang menyatakan bahwa underground economy di negara berkembang seperti Indonesia bisa memberikan kontribusi sebesar 30-40 persen untuk Produk Domestik Bruto (PDB). Persentase tersebut merupakan cerminan potensi kerugian negara dari sektor pajak yang diakibatkan adanya underground economy (CNN, 2018).

Data atau statistik penerimaan pajak memiliki peranan besar dalam penyusunan strategi pengamanan penerimaan pajak terutama sebagai bahan untuk analisis komprehensif atas kinerja penerimaan, tolak ukur efektivitas pemungutan pajak, pengukuran dampak perubahan kebijakan, serta penyusunan prakiraan penerimaan. Interpretasi yang tepat atas data atau statistik memungkinkan kita untuk menggali informasi berharga yang dapat digunakan dalam pengambilan kebijakan strategis. Selama tahun 2010 sampe dengan tahun 2017 kenaikan target penerimaan pajak berkisar antara 4\% sampai dengan 20\%. Tentunya bukan hal yang mudah bagi 
Direktorat Jenderal Pajak untuk mencapai target tersebut. Berkaca pada penerimaan pajak tahun-tahun sebelumnya, penerimaan pajak tidak pernah mencapai target. Ketidaktercapaian tersebut disebabkan salah satunya oleh regulasi perpajakan yang diterbitkan oleh Pemerintah.

Penerbitan regulasi perpajakan pada dasarnya dilaksanakan dalam rangka meningkatkan efisiensi dan efektivitas dalam pengumpulan pajak, meningkatkan keadilan dalam pengenaan pajak, serta mendukung program atau kebijakan yang dilaksanakan pemerintah. Berdasarkan batasan kewenangan yang diatur oleh peraturan perundang-undangan, Direktorat Jenderal Pajak memiliki kewenangan dalam proses penerbitan regulasi perpajakan dalam tahapan perumusan, pembahasan, dan/atau pengesahan. Dalam melaksanakan kewenangan diatas, Direktorat Jenderal Pajak melakukan upaya harmonisasi peraturan yang dibutuhkan dalam penyusunan regulasi perpajakan. Upaya harmonisasi tersebut meliputi kegiatan identifikasi, pembahasan, dan pemberian rekomendasi. Pada kegiatan pembahasan, Direktorat Jenderal Pajak melibatkan para pemangku kepentingan seperti asosiasi dan ahli ekonomi untuk mendapatkan pandangan perekonomian saat ini atau masa mendatang.

Penelitian terdahulu mengenai potensi kehilangan penerimaan pajak di beberapa negara telah beberapa kali dilakukan, diantaranya di Amerika Serikat (Gutmann, 1977), (Tanzi, 1983), Guyana (Faal, 2003), Kolombia (Schneider \& Hametner, 2014), Indonesia (Purnomo, 2010), (Sapardi, 2017), (Samuda, 2016). Menurut (Gunadi, 2004), Penelitian-penelitian tersebut berkaitan dengan potensi kehilangan penerimaan pajak akibat aktivitas underground economy. Peningkatan nilai underground economy akan mengurangi penerimaan negara dari sektor pajak yang pada gilirannya akan mempengaruhi kualitas dan kuantitas barang dan jasa publik yang bisa disediakan oleh Pemerintah. Hal itu diperkuat oleh pernyataan Presiden Jokowi dalam Nota Keuangan beserta RAPBN 2019 di Gedung MPR/DPR bahwa tidak tercapainya target penerimaan negara dari sektor pajak akibat adanya kegiatan underground economy sehingga Pemerintah perlu bersikap hati-hati dalam menghimpun penerimaan pajak (CNN, 2019).

Berdasarkan penjelasan diatas, penulis tertarik untuk menyajikan penelitian mengenai potensi kehilangan penerimaan pajak di Indonesia selama delapan tahun (periode 2010-2017). Penelitian dilakukan dengan mengukur besaran potensi kehilangan penerimaan pajak menggunakan dua metode. Pertama, menghitung potensi kehilangan penerimaan pajak akibat aktivitas underground economy melalui pendekatan moneter yaitu dengan melihat elastisitas permintaan uang kartal terhadap beban pajak yang diperkenalkan (Tanzi, 1983). Kedua, menghitung potensi kehilangan penerimaan pajak atas dasar realisasi penerimaan pajak selama tahun 2010-2017. Penelitian ini merupakan replikasi dari penelitian (Samuda, 2016) yang mengukur potensi kehilangan penerimaan pajak berdasarkan aktivitas underground economy di Indonesia melalui analisa permintaan uang kartal yang dipengaruhi oleh inflasi, beban pajak, tingkat suku bunga dan Produk Domestik Bruto. Penelitian oleh (Samuda, 2016) dilakukan di Indonesia selama kurun waktu 2001-2013 dengan hasil penelitian bahwa besaran aktivitas underground economy di Indonesia sebesar 8,33\% dari PDB dan rata-rata 
potensi kehilangan penerimaan pajak selama periode tersebut sebesar Rp11,712.86 milyar atau sekitar 1\% dari rata-rata PDB Indonesia per triwulan.

Factor-faktor yang akan diuji kembali dalam penelitian ini adalah inflasi, beban pajak, tingkat suku bunga dan Produk Domestik Bruto. Penelitian dilakukan dengan terlebih dahulu mengitung besaran underground economy untuk selanjutnya dilakukan estimasi perhitungan potensi kehilangan penerimaan pajak atas aktivitas underground economy selama periode tersebut. Perbedaan penelitian ini dengan penelitian sebelumnya adalah penambahan variabel independen yaitu korupsi, inovasi keuangan perbankan yang diwakili oleh jumlah kantor cabang bank umum dan perubahan variabel yang mewakili tingkat suku bunga yaitu BI rate dan BI 7 days repo rate. Penambahan variabel inovasi keuangan perbankan sejalan dengan hasil penelitian oleh (Purnomo, 2010), (Sapardi, 2017) dan (Iskandar \& Mulyawan, 2017) bahwa perkembangan jasa perbankan turut berpengaruh terhadap permintaan uang kartal. Sedangkan, penambahan variabel korupsi yang diwakili oleh besaran kerugian keuangan negara dinilai berpengaruh terhadap permintaan uang kartal dikarenakan para pelaku korupsi lebih gemar mempergunakan transaksi secara tunai agar sulit dilacak dan terbebas dari kewajiban membayar pajak. Selain itu, ditambahkan juga dengan perhitungan potensi kehilangan pajak atas dasar realisasi penerimaan pajak selama tahun 2010-2017 yang dilakukan dengan menghitung selisih dari target dan realisasi penerimaan pajak di Indonesia. Hasil perhitungan dari kedua metode diatas kemudian akan dianalisa hubungannya ditinjau dari penerbitan regulasi perpajakan oleh Pemerintah dalam tahun tersebut. Berdasarkan seluruh penjabaran diatas, maka judul penelitian ini adalah “Analisis Potensi Kehilangan Penerimaan Pajak di Indonesia (Tahun 2010-2017)".

Penelitian ini penting dilakukan untuk mengetahui bahwa setiap regulasi perpajakan yang diterbitkan oleh Pemerintah sedikit banyak akan berdampak pada penerimaan perpajakan pada tahun berjalan. Selain itu tujuan dari penelitian ini yaitu mengetahui potensi kehilangan penerimaan pajak di Indonesia menggunakan metode underground economy dan metode realisasi penerimaan pajak periode 2010 - 2017 serta menganalisis perbedaan potensi kehilangan penerimaan pajak di Indonesia ditinjau dari penerbitan regulasi perpajakan periode 2010 - 2017.

\section{Metode Penelitian}

Penelitian ini menggunakan pendekatan kuantitatif, yang memiliki aspek pengukuran secara obyektif terhadap fenomena sosial yang dijabarkan kedalam beberapa komponen masalah, variabel dan indikator untuk kemudian menghasilkan pemecahan masalah yang dapat terukur secara numerik.

Jenis data yang dipergunakan dalam penelitian ini adalah data sekunder, yaitu berupa data yang dimiliki oleh beberapa pihak. Data yang digunakan adalah data sekunder berdasarkan runtut waktu (time series) dalam rentang waktu 2010 - 2017. Sumber data dari penelitian berasal dari Badan Pusat Statistik (BPS), ICW, Bank Indonesia dan Departemen Keuangan. Adapun teknik pengumpulan data menggunakan archival research atau riset arsip. 


\section{Hasil dan Pembahasan}

\section{Perhitungan Potensi Kehilangan Penerimaan Pajak Menggunakan Metode Underground Economy}

Perhitungan potensi kehilangan penerimaan pajak menggunakan metode underground economy dilakukan pertama-tama dengan menghitung nilai underground economy melalui pendekatan moneter. Pendekatan moneter yang dimaksud adalah melalui model persamaan regresi yang dikonstruksikan oleh (Tanzi, 1983) dan (Faal, 2003) melalui pengukuran sensitivitas permintaan uang kartal. Model yang digunakan dalam penelitian ini untuk pengukuran sensitivitas permintaan uang kartal adalah regresi linier berganda. Agar hasil regresi sahih sehingga harus terpenuhi asumsi klasik, yaitu: normalitas, autokorelasi, multikolinieritas, heteroskedasititas.

a. Uji Normalitas

Hasil analisis terhadap asumsi normalitas Kolmogorov-Smirnov terhadap nilai residual dari persamaan regresi, menunjukkan bahwa nilai probabilitas sebesar 0,987. Hal ini menunjukkan bahwa 0,987>0,05, berarti dapat disimpulkan bahwa data terdistribusi normal.

Tabel 1

Hasil Uji Normalitas Kolmogorov-Smirnov

\begin{tabular}{lcc}
\hline & Unstandardized Residual & Kesimpulan \\
\hline Kolmogorov-Smirnov Z & 0.452 & Bebas Normalitas \\
\hline Asymp. Sig. (2-tailed) & 0.987 & Bebas Normalitas \\
\hline a. Test distribution is normal. & & \\
\hline Sumber: Lampiran 4 & &
\end{tabular}

b. Uji Multikolinieritas

Hasil analisis menunjukkan bahwa nilai VIF variabel independen dibawah nilai 10 dan tolerance value diatas 0,10 . Sehingga dapat disimpulkan bahwa tidak terjadi multikolinieritas dalam model regresi. Hasil yang diperoleh dapat dilihat pada tabel berikut:

\section{Tabel 2}

Hasil Uji Multikolinieritas

\begin{tabular}{lrrr}
\hline \multicolumn{1}{c}{ Variabel } & Tolerance & \multicolumn{1}{c}{ VIF } & Kesimpulan \\
\hline SUKU BUNGA (R) & 0.188 & 5.329 & Bebas Multikolinieritas \\
\hline PDB (Y) & 0.242 & 3.663 & Bebas Multikolinieritas \\
\hline INOVASI BANK (F) & 0.165 & 5.355 & Bebas Multikolinieritas \\
\hline INFLASI (I) & 0.507 & 1.972 & Bebas Multikolinieritas \\
\hline BEBAN PAJAK (T) & 0.266 & 5.041 & Bebas Multikolinieritas \\
\hline KORUPSI (C) & 0.672 & 1.488 & Bebas Multikolinieritas \\
\hline
\end{tabular}

a. Dependent Variable: UANG KARTAL (M)

Sumber: Lampiran 5 


\section{c. Uji Heteroskedastisitas}

Hasil pengujian heteroskedastisitas diperoleh nilai variabel independen sebesar (Sig.) >0,05 sehingga dapat disimpulkan tidak terjadi gejala heteroskedastisitas dalam model.

Tabel 3

Hasil Uji Heteroskedastisitas

\begin{tabular}{lcl}
\hline Variabel & Sig. & \multicolumn{1}{c}{ Kesimpulan } \\
\hline SUKU BUNGA (R) & 0.772 & Bebas Heteroskedastisitas \\
\hline PDB (Y) & 0.539 & Bebas Heteroskedastisitas \\
\hline INOVASI BANK (F) & 0.756 & Bebas Heteroskedastisitas \\
\hline INFLASI (I) & 0.863 & Bebas Heteroskedastisitas \\
\hline BEBAN PAJAK (T) & 0.991 & Bebas Heteroskedastisitas \\
\hline KORUPSI (C) & 0.829 & Bebas Heteroskedastisitas \\
\hline
\end{tabular}

a. Dependent Variable: RES2

Sumber: Lampiran 6

\section{d. Uji Autokorelasi}

Untuk mendeteksi adanya autokorelasi, dapat dilihat dari nilai Durbin Watson (DW). Dengan nilai DW sebesar 2.446 dimana angka tersebut lebih besar dari (4-du) yakni 2.1813 dan kurang dari (4-dl) yakni 2.8908. Artinya model yang digunakan dalam penelitian ini tidak mengalami autokorelasi namun juga tidak bebas dari autokorelasi.

\section{Tabel 4}

\section{Hasil Uji Autokorelasi}

\begin{tabular}{ccccccc}
\hline Model & DW & dl & du & 4-dl & 4-du & Keterangan \\
\hline Regresi & 2.446 & 1.1092 & 1.8187 & 2.8908 & 2.1813 & inkonklusif \\
\hline
\end{tabular}

a. Predictors: (Constant), TAX, INTEREST, BANK, INFLASI, INCOME, KORUPSI

b. Dependent Variable: MONEY

Sumber: Lampiran 7

e. Regresi Linear Berganda

Model yang digunakan dalam melakukan estimasi adalah sensitivitas dari permintaan uang kartal terhadap adanya beban pajak. Hal ini dilandasi oleh pemikiran bahwa uang kartal menjadi alat transaksi yang sering dipergunakan oleh para pelaku kegiatan underground economy karena sifatnya yang tidak mudah dilacak oleh otoritas pajak. Peningkatan permintaan uang kartal menjadi salah satu indikator adanya peningkatan underground economy. Model tersebut mengukur apakah perubahan beban pajak akan merubah permintaan uang kartal.

Oleh karena uang kartal merupakan bagian dari permintaan uang, maka model ini menggunakan model standar permintaan uang dengan menambahkan variabel pajak. Variabel ini ditambahkan karena pajak dapat memengaruhi 
permintaan uang kartal dengan menciptakan "insentif" menghindari pajak yaitu dengan menggunakan lebih banyak uang kartal untuk melakukan transaksi.

Berdasarkan apa yang telah disampaikan, maka dengan menggunakan metode analisis regresi linear berganda melalui program SPSS disajikan hasil regresi berganda untuk menguji pengaruh dari tingkat suku bunga, tingkat pendapatan, inovasi keuangan perbankan, dan tingkat inflasi, beban pajak dan korupsi pada tabel berikut:

\section{Tabel 5}

Hasil Uji Regresi Linear Berganda

\begin{tabular}{lcccc}
\hline Variabel & Koefisien & t hitung & Sign & t tabel \\
\hline Konstanta & 1.122 & & & \\
\hline SUKU BUNGA (R) & -0.021 & -0.532 & 0.597 & 2.0595 \\
\hline PDB (Y) & 0.743 & 10.301 & 0.542 & 2.0595 \\
\hline INOVASI BANK (F) & -0.088 & -1.925 & 0.0625 & 2.0595 \\
\hline INFLASI (I) & 0.007 & 1.417 & 0.1654 & 2.0595 \\
\hline BEBAN PAJAK (T) & 0.008 & 3.932 & 0,0003 & 2.0595 \\
\hline KORUPSI & 0.09 & 0.975 & 0.339 & 2.0595 \\
\hline Adjust R & 0.922 & & & \\
\hline
\end{tabular}

Sumber: Lampiran 8

f. Uji t-statistik

Pengujian t-statistik digunakan untuk menguji pengaruh parsial dari variabel variabel bebas terhadap variabel tidak bebasnya. Uji ini dilakukan dengan membandingkan nilai t hitung dengan nilai t tabel. Hipotesis dalam uji ini adalah sebagai berikut:

$\mathrm{HO}: \quad \beta \mathrm{i}=0$; variabel bebas mempunyai pengaruh signifikan terhadap variabel terikat

$\mathrm{H} 1: \beta \mathrm{i}>0$; variabel bebas tidak mempunyai pengaruh signifikan terhadap variabel terikat

Dengan ketentuan bahwa bila diperoleh:

Jika t-hitung > t-tabel maka $\mathrm{H} 0$ ditolak, artinya tidak terdapat pengaruh signifikan antara variabel bebas terhadap variabel terikat.

Jika t-hitung < t-tabel maka H0 tidak ditolak, artinya terdapat pengaruh signifikan antara variabel bebas terhadap variabel terikat.

Tabel 6

Hasil Uji T-statistik

\begin{tabular}{lccl}
\hline Variabel & t hitung & t tabel & Keterangan \\
\cline { 2 - 4 } SUKU BUNGA (R) & -0.532 & 2.0595 & Ho diterima \\
\hline PDB (Y) & 4.301 & 2.0595 & Ho ditolak \\
\hline INOVASI BANK (F) & -1.925 & 2.0595 & Ho diterima \\
\hline INFLASI (I) & 1.417 & 2.0595 & Ho diterima \\
\hline BEBAN PAJAK (T) & 1.932 & 2.0595 & Ho diterima \\
\hline KORUPSI & 0.975 & 2.0595 & Ho diterima \\
\hline
\end{tabular}


Sumber : Lampiran 8 (telah diolah kembali)

Berdasarkan hasil uji t-statistik diperoleh kesimpulan bahwa variabel suku bunga, inovasi keuangan perbankan, inflasi, beban pajak dan korupsi berpengaruh signifikan terhadap permintaan uang kartal. Sedangkan variabel pendapatan tidak berpengaruh signifikan terhadap permintaan uang kartal.

g. Koefisien Determinasi $\left(\mathrm{R}^{2}\right)$

Analisis ini digunakan untuk mengetahui seberapa besar pengaruh yang diberikan variabel independen terhadap variabel dependen yang ditunjukkan dalam persentase dari hasil analisis data diperoleh angka koefisien determinasi yang disesuaikan (adjusted $\mathrm{R}^{2}$ ) sebesar 0.922. Hal ini berarti 92,2 persen variasi perubahan permintaan uang kartal dijelaskan oleh variasi tingkat suku bunga (b1), tingkat pendapatan (b2), inovasi keuangan perbankan (b3), tingkat inflasi (b4), beban pajak (b5) dan korupsi (b6) Sementara sisanya sebesar 7,8 persen diterangkan oleh variabel lain yang tidak terdapat dalam model atas penulis teliti.

\section{Mengukur Besaran Underground Economy}

Hasil regresi linear berganda pada tabel tersebut menunjukkan persamaan regresi sebagai berikut:

$\mathrm{C}=1,122-0,021 \mathrm{~b} 1+0,743 \mathrm{~b} 2-0,088 \mathrm{~b} 3+0,007 \mathrm{~b} 4+0,008 \mathrm{~b} 5$

$+0,09 \mathrm{~b} 6+\mathrm{e}$

Hasil estimasi persamaan regresi berdasarkan tabel tersebut menunjukkan besarnya permintaan uang kartal secara keseluruhan baik yang digunakan untuk transaksi dalam aktifitas official economy (MOE) maupun underground economy (MUE). Sementara besarnya uang kartal riil yang digunakan dalam official economy (MOE) diperoleh dari hasil regresi berdasarkan tabel 5.6 dengan mengeluarkan variabel beban pajak (T) dari persamaan itu. Selisih antara kedua hasil estimasi tersebut menunjukkan besarnya uang kartal pada underground economy (MUE). Perhitungan jumlah uang kartal tersebut dapat dilihat pada lampiran 9.

Hasil perhitungan per triwulan dalam periode tahun 2010 - 2017 pada lampiran 8 menunjukkan bahwa jumlah uang kartal yang digunakan dalam perekonomian secara keseluruhan berkisar antara Rp2.144,32 triliun sampai dengan Rp3.938,21 triliun atau rata-rata sekitar Rp3.039,26 triliun per triwulan. Dengan kisaran jumlah uang kartal sebesar itu, rata-rata sekitar $74 \%$ per triwulan diantaranya merupakan jumlah uang kartal yang digunakan dalam kegiatan official economy. Dengan demikian, jumlah uang kartal yang digunakan dalam kegiatan underground economy (riil) berkisar antara Rp198,80 miliar sampai Rp1.653,40 triliun atau rata-rata sebesar Rp790,09 miliar per triwulan. Nilai ini setara dengan 26\% dari total jumlah uang kartal yang beredar dalam masyarakat.

Berdasarkan hasil perhitungan jumlah uang kartal dalam underground economy tersebut lebih lanjut dapat ditentukan nilai underground economy dengan 
mengasumsikan bahwa kecepatan perputaran uang pada underground economy sama dengan yang ada pada official economy (VUE = VOE).

Hasil perhitungan besaran nilai underground economy di Indonesia periode 2010-2017 pada lampiran 9 menunjukkan bahwa nilai underground economy nominal per triwulan dalam periode tersebut berkisar antara Rp25.435,64 triliun sampai Rp202.193,73 triliun. Secara rata-rata dalam periode tersebut nilai underground economy nominal mencapai Rp91.997,88 triliun atau setara dengan 40,21\% terhadap PDB nominal. Bila dibandingkan dengan hasil studi Scheiner dan Enster (2002) yang memperkirakan underground economy di negara-negara berkembang sekitar 35\% - 44\% serta sinyalemen Chatib Basri dan Faisal Basri (Gunadi, 2004) tentang kegiatan underground economy di Indonesia, maka hasil temuan dalam studi ini mendukung penelitian tersebut.

\section{Mengukur Potensi Kehilangan Penerimaan Pajak}

Berdasarkan hasil perhitungan estimasi potensi pajak pada lampiran 10, nilai potensi pajak yang tidak dilaporkan karena adanya kegiatan underground economy dalam periode 2010-2017 secara triwulanan menunjukkan kecenderungan yang berfluktuatif. Jika dalam awal tahun 2010 potensi pajak yang hilang diperkirakan mencapai Rp33,82 triliun hingga Rp92,50 triliun, maka memasuki tahun 2017 mencapai nilai sekitar Rp163,22 triliun hingga Rp180,91 triliun. Secara rata-rata dalam periode studi, potensi pajak dari kegiatan underground economy tumbuh sekitar $12,07 \%$ per triwulan dengan nilai berkisar sebesar Rp24,42 triliun hingga Rp180,91 triliun dengan rata-rata mencapai Rp89,84 triliun. Berikut disajikan tabel perhitungan potensi kehilangan pajak periode tahunan untuk tahun 2010 - tahun 2017.

Tabel 7

Kehilangan Penerimaan Pajak-Underground Economy

\begin{tabular}{cc}
\hline Tahun & $\begin{array}{c}\text { Potensi Kehilangan Penerimaan } \\
\text { Pajak } \\
\text { (triliun rupiah) }\end{array}$ \\
\hline 2010 & 273.89 \\
\hline 2011 & 382.45 \\
\hline 2012 & 294.51 \\
\hline 2013 & 152.52 \\
\hline 2014 & 191.75 \\
\hline 2015 & 452.05 \\
\hline 2016 & 443.09 \\
\hline 2017 & 684.65 \\
\hline Sum
\end{tabular}

Kecenderungan meningkatnya potensi kehilangan pajak akibat aktivitas underground economy diduga turut dipengaruhi oleh kebijakan perpajakan yang diterapkan oleh Pemerintah. Salah satu contohnya adalah penerapan tarif pengenaan 
Penghasilan Kena Pajak pada Wajib Pajak Badan sebesar 25\%. Tarif PPh Badan di Indonesia sebesar 25\% dari Penghasilan Kena Pajak (PKP) saat ini masih lebih tinggi dibandingkan negara-negara di Asia Tenggara. Seperti di Malaysia, tarif PPh badan berada di level $24 \%$. Sementara Thailand dan Vietnam masing-masing berada di tarif $22 \%$ dan $20 \%$ (CNN, 2019).

Pemerintah telah melakukan beberapa kebijakan untuk menarik para pelaku underground economy ini untuk membayar pajak, diantaranya dengan diberlakukan tax amnesty yang dibagi menjadi tiga periode selama tahun 2016 dan 2017 dengan total realisasi uang tebusan pajak sebesar Rp114,54 triliun (DJP, 2017). Namun, hal ini nyatanya tidak turut membuat penurunan potensi kehilangan penerimaan pajak akibat aktivitas underground economy.

\section{Perhitungan Potensi Kehilangan Penerimaan Pajak Menggunakan Metode Realisasi Penerimaan Pajak}

Hasil perhitungan potensi kehilangan penerimaan pajak menggunakan metode realisasi penerimaan pajak dihitung dari selisih antara target penerimaan negara dari sektor pajak dengan realisasi penerimaan pajak selama periode 2010 - 2017 yang dapat digambarkan dalam tabel berikut:

\section{Tabel 8}

Kehilangan Penerimaan Pajak-Realisasi Penerimaan Pajak

\begin{tabular}{cccc}
\hline Tahun & $\begin{array}{c}\text { Target } \\
\text { (triliun } \\
\text { rupiah) }\end{array}$ & $\begin{array}{c}\text { Realisasi } \\
\text { (triliun } \\
\text { rupiah) }\end{array}$ & $\begin{array}{c}\text { Kehilangan } \\
\text { Penerimaan Pajak } \\
\text { (triliun rupiah) }\end{array}$ \\
\hline 2010 & 661.49 & 627.88 & 33.61 \\
\hline 2011 & 763.67 & 742.71 & 20.96 \\
\hline 2012 & 885.02 & 835.87 & 49.15 \\
\hline 2013 & 995.21 & 921.39 & 73.82 \\
\hline 2014 & $1,072.37$ & 985.12 & 87.25 \\
\hline 2015 & $1,294.25$ & $1,060.86$ & 233.39 \\
\hline 2016 & $1,355.20$ & $1,105,97$ & 249,23 \\
\hline 2017 & $1,283.56$ & $1,151.02$ & 132.54 \\
\hline
\end{tabular}

Sumber: Dirjen Perpajakan RI

Berdasarkan tabel diatas dapat dilihat bahwa terdapat kehilangan penerimaan pajak berkisar antara Rp 20,96 triliun sampai dengan Rp 141,08 triliun rupiah. Beberapa hal yang mempengaruhi besaran kehilangan penerimaan pajak akibat tercapai atau tidak tercapainya target penerimaan serta pertumbuhan realisasi penerimaan beberapa jenis pajak selama periode tahun 2010-2017, antara lain sebagai berikut:

Selama tahun 2010 realisasi penerimaan pajak sebesar Rp627,88 triliun atau 94,92\% dari target penerimaan pajak sebesar Rp661,49 triliun. Kehilangan penerimaan pajak sebesar Rp33,61 triliun rupiah yang disebabkan oleh kenaikan tarif Penghasilan Tidak Kena Pajak (PTKP) dari Rp13.200.000 menjadi Rp15.840.000 yang diatur dalam Undang-Undang Nomor 36 Tahun 2008 tentang Perubahan 
Keempat atas Undang-Undang Nomor 7 Tahun 1983 tentang Pajak Penghasilan dan mulai berlaku tanggal 1 Januari 2009. Selain itu, hal lain yang turut menjadi penyebab kehilangan penerimaan pajak pada tahun 2010 merupakan akibat dari kebijakan sunset policy yang dikeluarkan oleh Pemerintah pada tahun 2009. Sunset policy merupakan program penghapusan sanksi administrasi Pajak Penghasilan sebagai bentuk pemberian fasilitas perpajakan yang diatur dalam Peraturan Menteri Keuangan Nomor: 66/PMK.03/2008 dan mulai berlaku tanggal 1 Januari 2008.

Selama tahun 2011 realisasi penerimaan pajak sebesar Rp742,74 triliun atau 97,26\% dari target penerimaan pajak sebesar Rp763,67 triliun. Kehilangan penerimaan pajak sebesar Rp 20,96 triliun disebabkan oleh banyaknya permohonan Surat Keterangan Bebas PPh Pasal 22 atas impor barang modal. Berdasarkan data BPS, impor barang modal (golongan mesin) ke Indonesia meningkat cukup signifikan sebesar US\$24,68 miliar (BPS, 2011). Selain itu, rendahnya penyerapan anggaran 2011, meningkatnya pertumbuhan restitusi yang mencapai $21,31 \%$, dari semula Rp26.594,10 miliar di tahun 2010 menjadi Rp32.262,07 miliar pada tahun 2011, dan meningkatnya pertumbuhan ekspor sebesar $29,05 \%$ dari semula US $\$ 157,78$ miliar menjadi US\$203,62 miliar.

Selama tahun 2012 realisasi penerimaan pajak sebesar Rp835,82 triliun atau 94,44\% dari target penerimaan pajak sebesar Rp885,02 triliun. Kehilangan penerimaan pajak sebesar Rp 49,15 triliun disebabkan realisasi yang tidak optimal dari penerimaan PBB karena adanya perubahan mekanisme pengenaan areal on shore berdasarkan Peraturan Menteri Keuangan Nomor: 15/PMK.03/2012 tentang Penatausahaan dan Pemindahbukuan Pajak Bumi dan Bangunan Sektor Pertambangan untuk Pertambangan Minyak Bumi, Gas Bumi dan Panas Bumi. Selain itu menurunnya kegiatan produksi pada sektor pertambangan dan penggalian, sehingga beberapa Wajib Pajak menurunkan pembayaran PPh Pasal 26.

Selama tahun 2013 realisasi penerimaan pajak sebesar Rp921,39 triliun atau 92,58\% dari target penerimaan pajak sebesar Rp995,21 triliun. Kehilangan penerimaan pajak sebesar Rp 73,82 triliun disebabkan kenaikan tarif Penghasilan Tidak Kena Pajak (PTKP) dari Rp15.840.000 menjadi Rp24.300.000 yang diatur dalam Peraturan Menteri Keuangan Nomor: 162/PMK.011/2012 tentang Penyesuaian Besarnya Penghasilan Tidak Kena Pajak dan mulai berlaku tanggal 1 Januari 2013. Selain itu, tidak tercapainya target realisasi diakibatkan oleh kinerja Wajib Pajak sektor pertambangan yang masih kurang meyakinkan sehingga berdampak pada menurunnya penggunaan jasa dari objek PPh Pasal 23, serta keputusan perusahaan-perusahaan besar di sektor pertambangan untuk tidak melakukan pembagian dividen.

Selama tahun 2014 realisasi penerimaan pajak sebesar Rp985,12 triliun atau 91,86\% dari target penerimaan pajak sebesar Rp1072,37 triliun. Kehilangan penerimaan pajak sebesar sebesar $\mathrm{Rp} 87,25$ triliun disebabkan antara lain oleh melemahnya kinerja perusahaan-perusahaan yang berada di sektor pertambangan yang masih belum pulih akibat dari menurunnya permintaan dunia terhadap barang 
komoditi yang berimbas pada penurunan harga komoditi. Imbas dari penurunan kinerja perusahaan di sektor pertambangan selama tahun 2013 mengakibatkan beberapa perusahaan besar tidak membagi dividen di tahun 2014 sehingga memberikan dampak yang kurang baik terhadap realisasi penerimaan PPh Pasal 23. Selain itu, tidak tercapainya target realisasi diakibatkan adanya kebijakan pemberian insentif pembebasan PPnBM terhadap mobil murah Low Cost Green Car (LCGC) yang menggeser selera dan konsumsi masyarakat terhadap mobil mewah yang diatur dalam Peraturan Menteri Perindustrian Nomor: No.33/M-IND/PER/7/2013 tentang Pengembangan Produksi Kendaraan Bermotor Roda Empat yang Hemat Energi dan Harga Terjangkau.

Selama tahun 2015 realisasi penerimaan pajak sebesar Rp1.060,86 triliun atau $81,97 \%$ dari target penerimaan pajak sebesar Rp1.294,25 triliun. Kehilangan penerimaan pajak sebesar sebesar Rp 233,39 triliun disebabkan oleh beberapa hal diantaranya, kebijakan Pemerintah menaikkan batas Penghasilan Tidak Kena Pajak (PTKP) dari Rp24.300.000 menjadi Rp36.000.000 sebagaimana diatur dalam Peraturan Menteri Keuangan Nomor: 122/PMK.010/2015 tentang Penyesuaian Besarnya Penghasilan Tidak Kena Pajak dan penerimaan PPN Impor yang dipengaruhi harga migas baik minyak mentah (CPO) maupun minyak olahan yang tengah turun ditambah rendahnya nilai impor tahun 2015 akibat rendahnya aktivitas industri domestik. Menurunnya aktivitas industri domestik tentu saja mempengaruhi nilai impor sebagai faktor input produksi yang secara langsung berkorelasi terhadap kinerja penerimaan PPN Impor. Selain itu, tidak tercapainya target realisasi diakibatkan pemebasan PPnBM pada beberapa jenis barang tertentu yang tercantum dalam Peraturan Menteri Keuangan Nomor: 106/PMK.010/2015 tentang Jenis Barang Kena pajak yang Tergolong Mewah Selain Kendaraan Bermotor yang Dikenai Pajak Penjualan atas Barang Mewah.

Selama tahun 2016 realisasi penerimaan pajak sebesar Rp1.105,97 triliun atau $81,12 \%$ dari target penerimaan pajak sebesar Rp1.355,20 triliun. Kehilangan penerimaan pajak sebesar Rp 249,23 triliun disebabkan oleh kebijakan Pemerintah menaikkan batas Penghasilan Tidak Kena Pajak (PTKP) dari Rp36.000.000 menjadi Rp54.000.000 sebagaimana diatur dalam Peraturan Menteri Keuangan Nomor: 101/PMK.010/2016 tentang Penyesuaian Besarnya Penghasilan Tidak Kena Pajak, adanya kebijakan tersebut mengakibatkan jumlah Wajib Pajak orang pribadi yang membayar pajak tahun 2016 menjadi berkurang.

Selama tahun 2017 realisasi penerimaan pajak sebesar Rp1.151,02 triliun atau 89,67\% dari target penerimaan pajak sebesar Rp1.283,56 triliun. Kehilangan penerimaan pajak sebesar Rp 132,54 triliun disebabkan naiknya batasan Penghasilan Tidak Kena Pajak (PTKP) pada bulan Juli 2016 menyebabkan perlambatan PPh Pasal 21 di semester 1 2017. Selain itu, terdapatnya penurunan tarif PPh Final atas pengalihan hak atas tanah/bangunan sebagaimana diatur dalam Peraturan Pemerintah Nomor: 34 Tahun 2016 tentang Pajak Penghasilan atas Penghasilan Hak Atas Tanah dan/atau Bangunan, dan Perjanjian Pengikatan Jual Beli atas Tanah dan/atau 
Bangunan Beserta Perubahannya, dimana tarif berlaku secara umum turun dari 5\% menjadi 2,5\% sehingga pada tahun 2017 realisasinya tumbuh negatif sebesar $18,1 \%$.

\section{Analisis Potensi Kehilangan Pajak di Indonesia Ditinjau dari Penerbitan Regulasi Perpajakan oleh Pemerintah Tahun 2010 - 2017}

Definisi dari "Potensi Kehilangan Pajak" adalah membandingkan perhitungan potensi kehilangan penerimaan pajak menggunakan metode underground economy dan perhitungan potensi kehilangan penerimaan pajak atas dasar realisasi penerimaan pajak ditinjau dari penerbitan regulasi perpajakan.

Pajak merupakan salah satu penerimaan negara yang penting bagi pelaksanaan dan pembangunan nasional serta bertujuan untuk meningkatkan kemakmuran dan kesejahteraan rakyat. Selama tahun 2010 sampai dengan tahun 2017 kenaikan target penerimaan pajak berkisar antara $4 \%$ sampai dengan $20 \%$. Tentunya bukan hal yang mudah bagi Direktorat Jenderal Pajak untuk mencapai target tersebut. Berkaca pada penerimaan pajak tahun-tahun sebelumnya, penerimaan pajak tidak pernah mencapai target. Ketidaktercapaian tersebut disebabkan salah satunya oleh regulasi perpajakan yang diterbitkan oleh Pemerintah.

Penerbitan regulasi perpajakan pada dasarnya dilaksanakan dalam rangka meningkatkan efisiensi dan efektivitas dalam pengumpulan pajak, meningkatkan keadilan dalam pengenaan pajak, serta mendukung program/kebijakan yang dilaksanakan pemerintah. Berdasarkan batasan kewenangan yang diatur oleh peraturan perundang-undangan, Direktorat Jenderal Pajak memiliki kewenangan dalam proses penerbitan regulasi perpajakan dalam tahapan perumusan, pembahasan, dan/atau pengesahan. Dalam melaksanakan kewenangan di atas, Direktorat Jenderal Pajak melakukan upaya harmonisasi peraturan yang dibutuhkan dalam penyusunan regulasi perpajakan. Upaya harmonisasi tersebut meliputi kegiatan identifikasi, pembahasan, dan pemberian rekomendasi. Pada kegiatan pembahasan, Direktorat Jenderal Pajak melibatkan para pemangku kepentingan seperti asosiasi dan ahli ekonomi untuk mendapatkan pandangan perekonomian saat ini atau masa mendatang.

Hasil perhitungan potensi kehilangan penerimaan pajak di Indonesia tahun 2010 sampai dengan tahun 2017 menggunakan metode underground economy dan metode realisasi penerimaan pajak secara singkat dapat digambarkan dalam grafik sebagai berikut: 


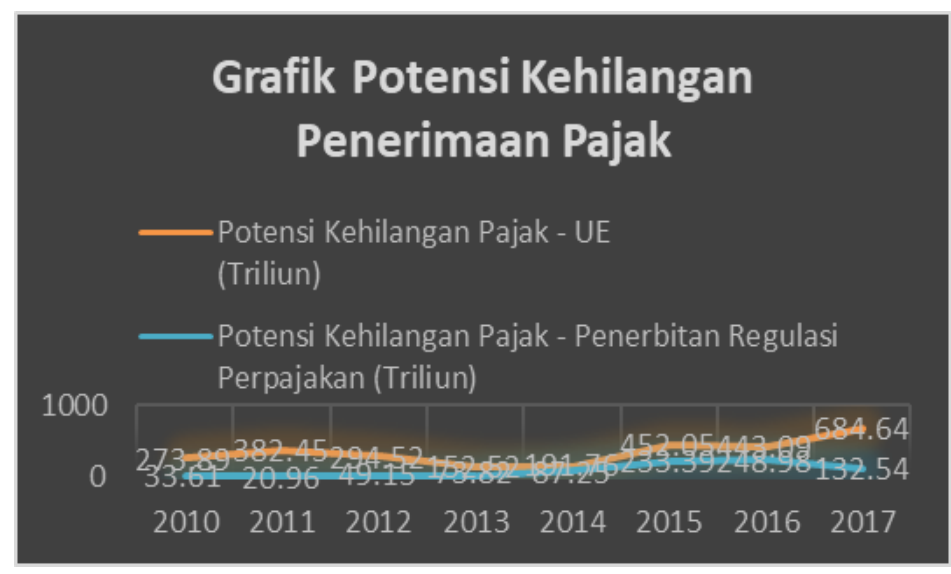

\section{Gambar 1 \\ Potensi Kehilangan Penerimaan Pajak}

Sumber: Data yang diolah

Dari data grafik diatas terdapat perbedaan naik dan turun potensi penerimaan pajak baik menggunakan metode perhitungan underground economy dan metode realisasi penerimaan pajak. Pada tahun 2011 terdapat kenaikan potensi penerimaan pajak menggunakan metode underground economy menjadi Rp382,45 triliun, sedangkan potensi kehilangan penerimaan pajak menggunakan metode realisasi penerimaan pajak turun dari tahun sebelumnya menjadi Rp20,96 triliun. Pada tahun 2012 terdapat penurunan potensi penerimaan pajak menggunakan metode underground economy menjadi Rp294,52 triliun, sedangkan potensi kehilangan penerimaan pajak menggunakan metode penerbitan realisasi penerimaan pajak naik dari tahun sebelumnya menjadi Rp49,15 triliun. Pada tahun 2013 terdapat penurunan potensi penerimaan pajak menggunakan metode underground economy menjadi Rp152,52 triliun, sedangkan potensi kehilangan penerimaan pajak menggunakan metode realisasi penerimaan pajak naik dari tahun sebelumnya menjadi Rp73,82 triliun. Pada tahun 2016 terdapat penurunan potensi penerimaan pajak menggunakan metode underground economy menjadi Rp443,09 triliun, sedangkan potensi kehilangan penerimaan pajak menggunakan metode realisasi penerimaan pajak naik dari tahun sebelumnya menjadi Rp248,98 triliun. Pada tahun 2017 terdapat kenaikan potensi penerimaan pajak menggunakan metode underground economy menjadi Rp684,64 triliun, sedangkan potensi kehilangan penerimaan pajak menggunakan metode realisasi penerimaan pajak turun dari tahun sebelumnya menjadi Rp132,54 triliun.

Perbedaan naik dan turun potensi penerimaan pajak yang dihitung berdasarkan kedua metode diatas dipengaruhi oleh beberapa hal diantaranya:

1) Kenaikan potensi kehilangan penerimaan pajak menggunakan metode underground economy turut disebabkan oleh adanya regulasi perpajakan yang dikeluarkan oleh Pemerintah, terutama apabila regulasi tersebut menyebabkan jumlah pajak yang dibebankan ke masyarakat lebih besar daripada sebelumnya. Sebagai contoh pada tahun 2011 terbit regulasi perpajakan berupa Peraturan Dirjen Pajak Nomor: PER-64/PJ/2010 tentang Pengenaan Pajak Bumi dan 
Bangunan Sektor Perkebunan yang mengatur tentang kenaikan NJOP Sektor Perkebunan sebagai Dasar Pengenaan Pajak Bumi dan Bangunan untuk Objek Pajak Sektor Perkebunan dan mulai berlaku tanggal 1 Januari 2011. Naiknya tarif NJOP akan menimbulkan keengganan para pelaku underground economy untuk membayar pajak dan mengganggap lebih baik menyimpan uang untuk memenuhi kebutuhan daripada menyetorkan ke negara sehingga akan meningkatkan kegiatan underground economy dan turut meningkatkan potensi kehilangan penerimaan pajaknya. Namun, di sisi lain jumlah pajak yang dapat ditarik oleh Pemerintah lebih banyak akibat naiknya tarif NJOP ini yang kemudian akan meningkatkan realisasi penerimaan pajak pada tahun 2011 dan menurunnya kehilangan penerimaan pajak pada tahun tersebut menjadi Rp20,96 triliun, turut mempengaruhi kehilangan penerimaan pajak tahun 2011 .

2) Pada tahun 2012 terdapat kebijakan insentif fiskal yang diberikan Pemerintah kepada pelaku industri minyak goreng melalui Peraturan Dirjen Pajak Nomor Per12/PJ/2011 tentang Tata Cara Penatausahaan Pajak Pertambahan Nilai yang Ditanggung Pemerintah atas Penyerahan Minyak Goreng Kemasan Sederhana dan/atau Minyak Goreng Sawit Curah di dalam Negeri. Insentif yang diterima berupa PPN terutang atas penyerahan Minyak Goreng Kemasan Sederhana dan/atau Minyak Goreng Sawit Curah ditanggung oleh Pemerintah. Terbitnya regulasi perpajakan ini diharapkan dapat menarik minat para pelaku underground economy untuk masuk ke dalam official economy sehingga potensi kehilangan penerimaan pajak dari underground economy dapat turun, hal ini tercermin dari turunnya potensi kehilangan penerimaan pajak tahun tersebut menjadi Rp294,52 triliun. Namun, seperti halnya mata uang yang mempunyai dua sisi, terbitnya regulasi perpajakan ini menimbulkan meningkatnya kehilangan penerimaan pajak dari pos penerimaan pajak dari Pajak Pertambahan Nilai (PPN) sehingga pada tahun 2012 kehilangan penerimaan pajak meningkat menjadi Rp49,15 triliun. Kebijakan insentif fiskal memang sering dilakukan oleh Pemerintah dengan tujuan mendukung daya beli masyarakat, terutama untuk kebutuhan rumah tangga.

3) Pada tahun 2013 diterbitkan beberapa regulasi perpajakan mengenai insentif fiskal yang diberikan oleh Pemerintah yaitu Peraturan Menteri Keuangan RI Nomor: 120/PMK.04/2013 tentang Perubahan Ketiga atas Peraturan menteri Keuangan Nomor: 147/PMK.04/2011 tentang Kawasan Berikat dan Peraturan Menteri Keuangan RI Nomor: 121/PMK.011/2013 tentang Jenis Barang Kena Pajak yang Tergolong Mewah selain Kendaraan Bermotor yang Dikenai Pajak Penjualan atas Barang Merah. Dalam regulasi perpajakan mengenai kawasan berikat, Pemerintah memberikan kelonggaran kewajiban ekspor untuk meningkatkan produksi dan menguntungkan masyarakat karena produk dalam negeri akan diisi oleh produk kualitas ekspor karena dalam ketetapan sebelumnya di kawasan berikat alokasi penjualan produk dalam negeri sebesar $25 \%$ sedangkan $75 \%$ merupakan ekspor. Sekarang, alokasi penjualan produk dalam negeri naik menjadi 50\%. Sedangkan, regulasi perpajakan mengenai produk barang yang dihapuskan dari pengenaan 
PPnBM terdiri dari enam kategori yaitu peralatan rumah tangga dengan batasan harga di bawah Rp5.000.000 atau Rp10.000.000, televisi dengan harga dan ukuran masing-masing dibawah Rp10.000.000 dan 40 inch, lemari pendingin dengan harga dibawah Rp10.000.000. mesin pengatur suhu ruangan (AC) dengan harga dibawah Rp8.000.000, pemanas air dengan harga dibawah Rp5.000.000 dan proyektor serta produk saniter dengan harga dibawah Rp10.000.000. Kebijakan ini diterbitkan dengan tujuan untuk meningkatkan kinerja produk domestik dalam rangka bersaing dengan produk impor. Terbitnya regulasi perpajakan ini diharapkan dapat menarik minat para pelaku underground economy untuk masuk ke dalam official economy sehingga potensi kehilangan penerimaan pajak dari underground economy dapat turun. Selama tahun 2013 terjadi penurunan potensi kehilangan penerimaan pajak menjadi Rp152,52 triliun. Namun, terbitnya regulasi perpajakan ini menimbulkan meningkatnya kehilangan penerimaan pajak dari pos penerimaan pajak dari PPN dan PPnBM sehingga pada tahun 2013 kehilangan penerimaan pajak meningkat menjadi Rp73,82 triliun.

4) Pemerintah mengeluarkan regulasi perpajakan yaitu Undang-Undang Nomor: 11 Tahun 2016 tentang Pengampunan Pajak berpengaruh terhadap potensi kehilangan penerimaan pajak tahun 2016 dan 2017. Pengampunan pajak adalah program pengampunan yang diberikan oleh Pemerintah kepada Wajib Pajak meliputi penghapusan pajak yang seharusnya terutang, penghapusan sanksi administrasi perpajakan serta penghapusan sanksi pidana di bidang perpajakan atas harta yang diperoleh pada tahun 2015 dan sebelumnya belum dilaporkan dalam Surat Pemberitahuan Tahunan, dengan cara melunasi seluruh tunggakan pajak yang dimiliki dan membayar uang tebusan. Pemberian insentif fiskal oleh Pemerintah berupa pengampunan pajak merupakan salah satu cara untuk menarik pajak dari para pelaku underground economy yang sebelumnya tidak melakukan pelaporan pajak. Hal ini dicerminkan dari turunnya potensi kehilangan penerimaan pajak dari underground economy sebesar Rp443,09 triliun. Namun, seperti yang terjadi pada tahun-tahun sebelumnya bahwa kebijakan insentif fiskal yang dikeluarkan Pemerintah disatu sisi akan menimbulkan kehilangan penerimaan pajak yang seharusnya diperoleh oleh Negara. Hal ini dapat terlihat dari tidak tercapainya target realisasi penerimaan pajak tahun 2016 sebesar Rp248,96 triliun.

5) Pengampunan pajak yang berlangsung sampai tahun 2017 berhasil meningkatkan realisasi penerimaan pajak tahun 2017 serta mengurangi kehilangan penerimaan pajak sebesar Rp132,54 triliun. Namun, ditahun yang sama terdapat kenaikan potensi penerimaan pajak dari kegiatan underground economy sebesar Rp684,64 triliun meskipun pada tahun tersebut program pengampunan pajak masih berjalan. Hal ini dapat menjelaskan bahwa adanya insentif fiskal yang diberikan oleh Pemerintah nyatanya tidak dapat meningkatkan rasa kepercayaan masyarakat terhadap Pemerintah. Masyarakat secara umum dan para pelaku underground economy menganggap institusi perpajakan sarat dengan korupsi, sehingga ada 
kekhawatiran bahwa pajak yang disetorkan hanya akan dikorupsi oleh para pegawai pajak. Salah satu kasus penggelapan pajak yang didalangi oleh Gayus Tambunan-seorang pegawai pajak dengan rekening bernilai milyaran rupiah yang tidak mungkin bisa diperoleh dari penghasilan sebagai pegawai negeri sipil semakin mengurangi kepercayaan publik terhadap Pemerintah, khususnya institusi pajak. Setiap regulasi perpajakan yang diterbitkan oleh Pemerintah, nyatanya berdampak pada potensi kehilangan penerimaan pajak ditinjau dari respon para pelaku underground economy maupun realisasi pajak yang tercapai pada tahun berjalan.

\section{Kesimpulan}

Penelitian ini dilakukan untuk mengukur besarnya potensi kehilangan penerimaan pajak di Indonesia menggunakan metode underground economy di Indonesia dan metode potensi kehilangan pajak atas dasar realisasi penerimaan pajak periode 20102017 untuk kemudian dilakukan analisis ditinjau dari penerbitan regulasi perpajakan nasional. Berdasarkan hasil perhitungan dan analisis yang telah dilakukan, maka simpulan yang dapat diambil dari penelitian ini adalah sebagai berikut: 1) Potensi kehilangan penerimaan pajak karena adanya kegiatan underground economy dalam periode 2010-2017 menunjukkan kecenderungan yang berfluktuatif. Jika dalam awal tahun 2010 potensi pajak yang hilang diperkirakan mencapai Rp33,82 triliun hingga Rp92,50 triliun, maka memasuki tahun 2017 mencapai nilai sekitar Rp163,22 triliun hingga Rp180,91 triliun. 2) Berdasarkan metode realisasi penerimaan pajak di Indonesia periode 2010-2017 berkisar antara Rp 20,96 triliun sampai dengan Rp 141,08 triliun rupiah. Selama tahun 2010-2017 terdapat kecenderuangan naiknya kehilangan penerimaan pajak kecuali pada tahun 2011 dan tahun 2017 yang disebabkan oleh keadaan ekonomi Indonesia pada tahun berjalan. 3) Terdapat perbedaan potensi kehilangan penerimaan pajak dengan menggunakan kedua metode diatas. Secara umum, potensi kehilangan penerimaan pajak menggunakan metode perhitungan aktivitas underground economy lebih tinggi daripada potensi kehilangan pajak atas realisasi penerimaan pajak di Indonesia. Selain itu, setelah dilakukan analisis perbedaan dari perhitungan potensi kehilangan penerimaan pajak dari kedua metode tersebut ditinjau dari penerbitan regulasi perpajakan oleh Pemerintah diperoleh kesimpulan bahwa penerbitan regulasi perpajakan mempengaruhi naik dan turunnya penerimaan pajak di Indonesia. Pada dasarnya penerbitan regulasi perpajakan dilakukan dalam rangka meningkatkan efisiensi dan efektivitas dalam pengumpulan pajak, meningkatkan keadilan dalam pengenaan pajak, serta mendukung program yang dilaksanakan pemerintah. Namun, dalam setiap regulasi perpajakan yang diterbitkan terdapat efek samping yang dialami dalam penerimaan perpajakan Indonesia pada tahun berjalan. Contohnya seperti penerbitan regulasi terkait kebijakan fiskal bagi kebutuhan pokok yang sering dilakukan oleh Pemerintah dengan tujuan mendukung daya beli masyarakat namun adanya kebijakan insentif tersebut dapat meningkatnya kehilangan penerimaan pajak dari pos penerimaan pajak dari Pajak Pertambahan Nilai (PPN). 


\section{BIBLIOGRAFI}

Achmadi, Geri. (2007). Mengenal seluk beluk uang. Yudhistira Ghalia Indonesia. Google Scholar

Arfin. (2018). Risiko dan Peluang Terjadinya Korupsi di Sektor Pajak. In Simposium Nasional Keuangan Negara.

CNN. (2019). Benahi Sistem Dahulu, Turunkan Tarif PPh Badan Kemudian. Retrieved fromhttps://www.cnnindonesia.com/ekonomi/20190109115636-532

359526/benahi-sistem-dahulu-turunkan-tarif-pph-badan-kemudian [ 11 Agustus 2019 ].

Direktorat Jenderal Perpajakan. (2016). Analisis Potensi Kehilangan Penerimaan Pajak Di Indonesia (Tahun 2010-2017). Universitas Bakrie.

Faal, Ebrima. (2003). Currency demand, the underground economy, and tax evasion: The case of Guyana. Google Scholar

Gunadi, Aloysius. (2004). Krisis dan Underground Economy di Indonesia. Badan Perencanaan Dan Pembangunan Nasional. Google Scholar

Gutmann, Peter M. (1977). The subterranean economy. Financial Analysts Journal, 33(6), 26-27. Google Scholar

Indonesia, Bank. (2018). BI 7-day (Reverse) Repo Rate (p. 23 November 2018). p. 23 November 2018. Retrieved from https:/www.bi.go.id/id/moneter/bi-7day$\mathrm{RR} /$ penjelasan/Contents/Default.aspx

Iskandar, Azwar, \& Mulyawan, Andi Wawan. (2017). Analisis Underground Economy Indonesia dan Potensi Penerimaan Pajak (Analysis of Underground Economy of Indonesia and Tax Revenue Potential). Jurnal Info Artha PKN-STAN, 1. Google Scholar

Kusuma, Hendra. (2018). Penerimaan Perpajakan 2017 Capai Rp 1.339 Triliun, 91\% dari Target. Detik. Finance, 2. Google Scholar

Mankiw, G. (2007). Makroekonomi. In Jakarta: Penerbit Erlangga.

Nizar, Muhammad Afdi, \& Purnomo, Kuntarto. (2011). Potensi Penerimaan Pajak. Kajian Ekonomi Dan Keuangan, 15(2), 1-36. Google Scholar

Purnomo, Kuntarto. (2010). Estimasi Underground Economy di Indonesia Periode 2000-2009 Melalui Pendekatan Moneter. Skripsi S1 Fakultas Ekonomi, Universitas Indonesia. Google Scholar

Samuda, Sri Juli Asdiyanti. (2016). Underground economy in Indonesia. Buletin Ekonomi Moneter Dan Perbankan, 19(1), 39-56. Google Scholar 
Btari Mutia Anggraeni

Sapardi, Tenang. (2017). Estimasi Potential Loss Penerimaan Pajak dari Kegiatan Underground Economy dengan Pendekatan Moneter. Media Ekonomi, 21(1), 7186. Google Scholar

Schneider, Friedrich, \& Hametner, Bettina. (2014). The shadow economy in Colombia: Size and effects on economic growth. Peace Economics, Peace Science and Public Policy, 20(2), 293-325. Google Scholar

Tanzi, Vito. (1983). The underground economy in the United States: annual estimates, 1930-80. Staff Papers, 30(2), 283-305. Google Scholar

\section{Copyright holder:}

Btari Mutia Anggraeni (2021)

First publication right:

Journal Syntax Literate

This article is licensed under:

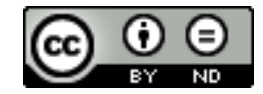

